\title{
Trend and noise: long-term changes of phytoplankton in the Keszthely Basin of Lake Balaton, Hungary
}

\author{
J. Padisák and L. Koncsos
}

\section{Introduction}

Lake Balaton is the largest shallow lake in Central Europe (length: $77.9 \mathrm{~km}$; average width: $7.2 \mathrm{~km}$; surface area: $593 \mathrm{~km}^{2}$; mean depth: $3.14 \mathrm{~m}$, theoretical retention time: 3-8 years; catchment area: 5182 $\mathrm{km}^{2}$ ). The Zala River, which enters the lake at the SW shore, drains an area of $2622 \mathrm{~km}^{2}$. As a result of the increased phosphorus load, the originally mesotrophic lake underwent rapid eutrophication in the 1960s-1970s (HERODEK 1984). Between 1975 and 1981, the total P load was estimated as $2.47 \mathrm{~g}$ $\mathrm{m}^{-2}$ year $^{-1}$ in the western part of the lake, and $0.31 \mathrm{~g}$ $\mathrm{m}^{-2}$ year $^{-1}$ in the eastern part (SOMLYÓDI \& JOLÁNKAI 1986). As a consequence of the morphometric and loading conditions, a sharp trophic gradient has developed in the lake.

In the early 1980 s, a large-scale eutrophication management program was started (ISTVANOVICS et al. 1997), which included the installation of a large water quality protecting reservoir (more than half of its $80-\mathrm{km}^{2}$ surface area being wetland) at the inlet of the major river. So far, the whole management program has resulted in approximately $50-60 \%$ reduction of the biologically available P (BAP) load of the lake. This load reduction was expected to slightly inhibit the development of phytoplankton in the lake (HERODEK 1984). In parallel to load reduction, the humic material load of the Keszthely Basin increased, since the entire discharge of the largest river has been filtered through a swampy wetland area.

From this pattern, it is expected to see:

1. A trendlike increase of phytoplankton biomass during the eutrophication phase (prior to 1985) combined with a proliferation of heterocytic cyanobacteria.

2. A trendlike decrease of phytoplankton biomass after restoration has started (1985).

3. An increase in the biomass share of actually or potentially mixotrophic species (especially flagellates) as a consequence of increased organic load of the basin, due to humic materials input from the wetland of the protecting reservoir.

Phytoplankton species have short doubling times - under natural conditions populations at the log phase of increase usually exhibit doubling times of 2-6 days depending on their size, morphology and intrinsic capacities. It was shown in many studies dealing with the succession of phytoplankton that stochasticity of weather conditions and other unexpected events may interfere with regular patterns of succession, sometimes only reversing its sequence but in other cases shifting it, which results in a very different successional pathway. Moreover, the actual biomass of phytoplankton in shallow lakes is often dependent upon the release of internally stored $\mathrm{P}$, of which some has also been weather dependent. Therefore, it is also expected that

4. There will be a 'noise' on the trends that can be forecasted from expectations numbered here from 1 to 3 .

This paper describes phytoplankton changes in the 19 years between 1982 and 2000 in the Keszthely Basin of the lake. Special attention will be paid to Cylindrospermopsis raciborskit, a bloom-forming subtropical cyanobacterium. Earlier data indicated that the occurrence of its blooms depends both on hydrometeorological conditions and the P-pool of the sediments (PADISAK \& ISTVANOVICS 1997, PADISÁK 1998). The basic question is whether the period of water quality restoration can really be attributed to successful management or is it merely a consequence of an ideal combination of hydrometeorological circumstances.

\section{Sources of data, methods and modelling}

Some of the phytoplankton data used in this paper come from the archives of the Middle Tansdanubian Water Authority (1983-1988). For the period 1989-2000, data from the present study are used; these have a sampling frequency varying from 3 days to biweekly. However, occasionally there are 4- to 6week gaps between samplings, due to unstable ice 
conditions. The phytoplankton (a minimum of 400 settling units per sample) was counted using an inverted microscope; biomass (wet weight) was estimated volumetrically (PADISAK et al. 1999, PADISÁK \& ADRIAN 1999). In order to avoid errors that may have arisen due to irregular sampling, annual average biomass was estimated in two steps: first, monthly averages were calculated, and then these were averaged to get annual means. In order to obtain annual maxima, individual species counts were averaged with the respective species counts for the sampling dates immediately prior to, and immediately after, the occurrence of the maximum, at each recorded maximum. In this way, an index of the phytoplankton closest to the anticipated late summer equilibrium phase was obtained (SOMmER et al. 1993). For cluster analysis, the Czekanowsi index (CZEKAnOwsKi 1909) and WPGMA fusion algorithm were applied using the SynTax III program package (PODANI 1988).

In addition to cluster analysis, an ecological model was developed and used to estimate the levels of phytoplankton biomass, and to evaluate the effectiveness of eutrophication control measures.

The applied model is capable of describing the non-linear mechanisms of eutrophication by a dynamic mass balance and, therefore,:

- the relationship between algal biomass and external nutrient load,

- the impact of weather conditions on algal growth, and

- the role of sediment influencing the internal load.

The complete model system incorporates three submodels: the hydrodynamic, transport and water quality submodels.

For computation of the horizontal convection and dispersion in the mass-balance, a two-dimensional hydrodynamic and transport model was utilized. The water quality submodel and its structure are presented in Fig. 1.

The applied model was based on careful analysis of the available data and previous modelling studies of Lake Balaton (SOMLYÓDY \& VAN STRATEN 1986) and other lakes.

The main processes of the model which describes a simple P cycle with seven state variables are briefly summarised, without explanation of the model equations. The model uses one algal group, which is in this case a single species, C. raciborskii. Algae take up the bulk of the inorganic $P$ that enters the water. Inorganic $\mathrm{P}$ is divided into two model state variables - dissolved reactive phosphorus (DRP) and particulate inorganic phosphorus.

Algal growth depends on $\mathrm{P}$, light and temperature limitations. Background light extinction is consid-

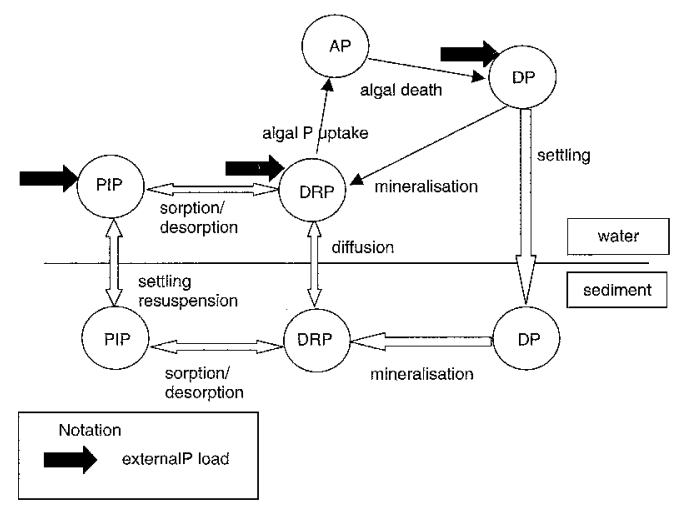

Fig. 1. Structure of the dynamic P model (model state variables: AP, algal phosphorus; DP, detritus phosphorus; DRP, dissolved reactive phosphorus; PIP, particulate inorganic phosphorus).

ered to be a function of the concentration of the humic materials. Wind-induced resuspension, and its impact on the light conditions, have been systematically investigated and included in the model structure as follows - a dynamic suspended solid model was constructed, which is capable of describing the wave motion due to episodic wind events. Another submodel computes bottom shear stress and resuspension flux associated with wave motion. With the help of the mass balance equation, the suspended solid concentration can be determined. The extinction coefficient can also then be computed simultaneously, based on a linear relationship.

The same temperature function (with optimal and critical values) as in previous Lake Balaton models was applied to limitation (KuTAS \& HeRODEK 1982, SOMLYÓdy \& VAN STRATEN 1986). Algal decay and mineralization are also temperature dependent.

$\mathrm{N}$-fixation was considered in the model structure as an additional source of $\mathrm{N}$-uptake. Its intensity influences the algal growth rate - based on experiments, it was assumed that the growth rate is reduced to $70 \%$ of maximal rate if $\mathrm{N}$-fixation reaches $100 \%$ of the algal $N$-uptake.

The model contains a more detailed sediment submodel, as shown in Fig. 1. The interaction between DRP and PIP is described by an equilibrium concentration both in water and sediment. Particulate $\mathrm{P}$ (PIP and DP) enters the sediment via settling, and recycling is also possible due to diffusion, which depends on sorption and several other processes. The submodel includes a $\mathrm{P}$ sorption isotherm that describes the relationship between the sediment $P$ pool and the dissolved inorganic P concentration (DRP) in the interstitial water. The isotherm sup- 
plies the model with 'memory' and thus it may suitably describe feed-back effects, following changes of loads, as well as the long-term behaviour of the system. The active sediment layer is a function of the suspended solids, deposition, carbonate removal and burial.

The model utilises data coming from different sources. Wind speed and direction data were measured hourly by the Hungarian Meteorological Service. Daily irradiation data were available from the database of the Central Institute for Atmospheric Physics. Water chemistry, nutrient load and water temperature data were measured by the West Danubian District Water Authority on almost a daily basis.

\section{Results and discussion}

\section{Eutrophication period}

Quantitative phytoplankton data prior to and during the rapid eutrophication of the Keszthely Basin of Lake Balaton are available in several publications (TAMÁs 1965, 1967, 1969, 1972, 1974, 1975, Herodek \& TAMÁs 1975 , Vörös 1980, OláH et al. 1981, PadisÁK \& G.TótH 1991, Padisák 1993). Even though the data in these publications are sporadic and have irregular temporal distributions within individual years, the eutrophication trend from the 1960 s to the 1980 s-1990s can be clearly shown (Fig. 2a). During this period, the annual average rose from $1000-2000 \mu \mathrm{g} \mathrm{L}^{-1}$ to $>20,000 \mu \mathrm{g}$ $\mathrm{L}^{-1}$, which, in terms of trophic states, indicates a change from meso-eutrophic to hypertrophic levels. In the papers cited above and in others, a shift in phytoplankton composition is also clearly documented - by the 1970s, heterocytic cyanobacteria (many of them was not recorded in the lake beforehand) became overwhelmingly dominant in the summer-autumn period (data are not shown here, see PADISÁK \& REYNOLDS 1998 for details).

\section{Restoration period}

Experience shows that the response (decrease) of phytoplankton, either in terms of biomass or chlorophyll $a$, to external P-load reduction may be significantly delayed. Based on the VolleNWEIDER \& KEREKES (1982) model on the restoration experience of many lakes, it can be shown (mathematical descriptions are not detailed here) that the equation given there can be simplified to

$$
2 \sqrt{ } \tau=\eta / 1-\eta
$$

where $\tau$ is the average retention time of water and $\eta$ is the annual average $P$ retention capacity of the lake. The above equation simply states that lakes with short retention times have a smaller $\mathrm{P}$ retention capacity than those with longer retention times. Restoration experiences (SAS 1989), however, show that the behaviour of some lakes deviates significantly from this simple model. In summary, in Lake Balaton, a rather long lag period (10-15 years) after a decreasing external load can be expected before a trophic change response occurs.

Phytoplankton biomass in Keszthely Basin remained practically unchanged during approximately the first 10 years after restoration had started (Fig. 2a). It was also shown that different guilds of the cyanobacteria responded differently - non-N-fixers followed changes in the $\mathrm{N} / \mathrm{P}$ loading ratio, N-fixers other than Cylindrospermopsis raciborskii decreased in parallel to external P-load, while C. raciborskii did not show any relationship with the variables of external load (PADISÁK \& IstVÁNOVICS 1997), most probably because its annual biomass is influenced by the sedimentary P-pool (internal load) and certain weather conditions.

The response of phytoplankton to P-load reduction has commonly been measured as a decrease in annual average or annual maximum biomass. In the Keszthely Basin, both measures showed a marked decrease after 1990 (Figs 2b and $2 \mathrm{~d}$ ). However, the most effective measure is the extension of the period with high (defined here as $>20 \mathrm{mg} \mathrm{L}^{-1}$ ) biomass (Fig. 2c). While such periods previously lasted for months (usually between June and mid-October), during the last several years phytoplankton biomass has remained at a high level for only a short period (2-3 weeks) or has not reached this critical level at all $(1997,1999,2000)$. The contribution of cyanoprokaryotes to annual average biomass (Fig. 2e) decreased to a much lesser extent than the other variables investigated herein. Nevertheless, the overall trend of phytoplankton 

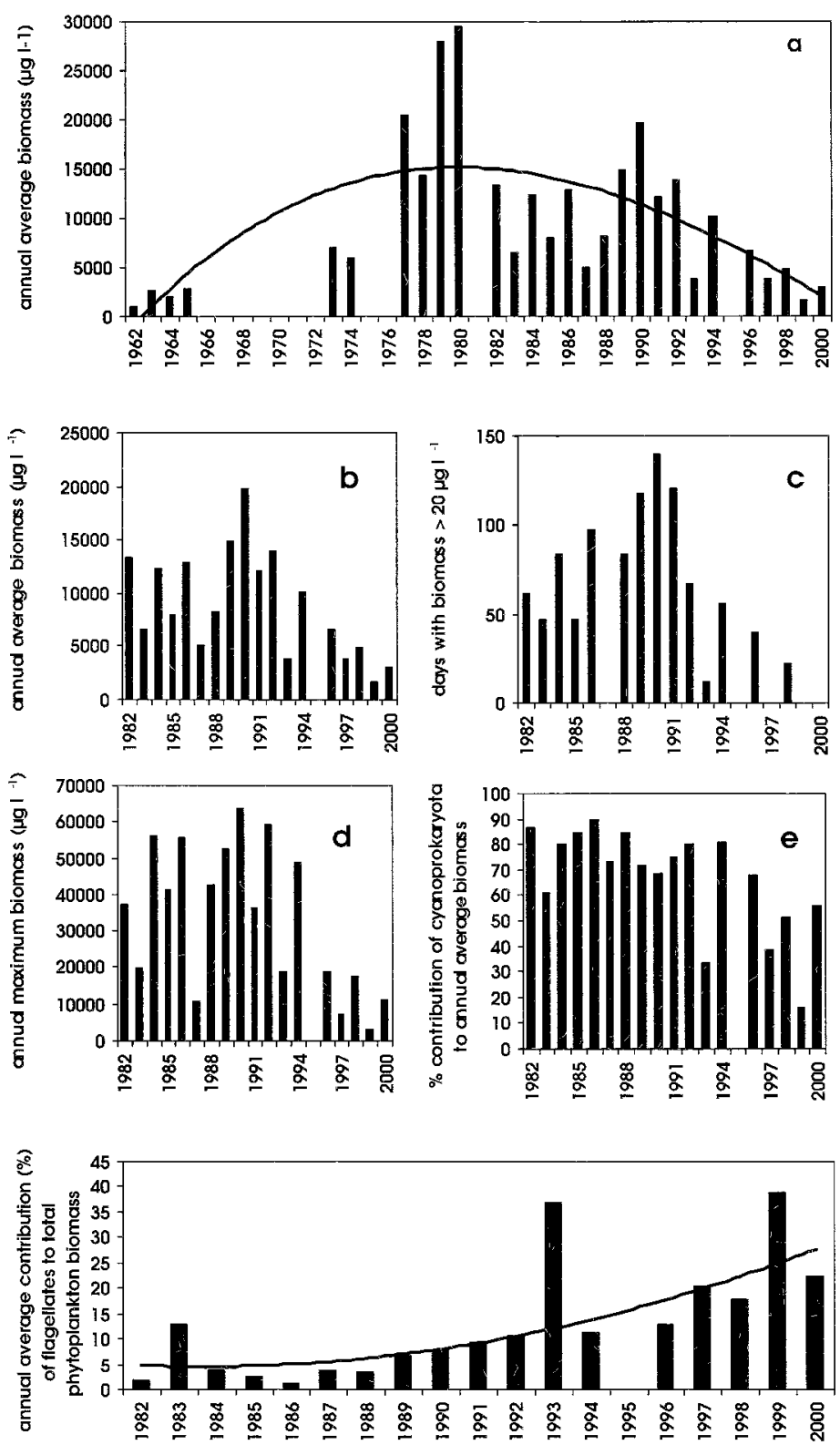

Fig. 2. (a) Annual average phytoplankton biomass in the Keszthely Basin of Lake Balaton between 1962 and 2000. Trendline (third-order orthogonal polynomial) is also indicated in the graph. (b) Annual average phytoplankton biomass in the Keszthely Basin of Lake Balaton between 1982 and 2000. (c) Number of days with phytoplankton biomass $>20 \mu \mathrm{g} \mathrm{L}^{-1}$ in the years 1982-2000 in the Keszthely Basin of Lake Balaton. (d) Late summer maximum of phytoplankton biomass in the Keszthely Basin of Lake Balaton between 1982 and 2000. (e) Contribution (\%) of cyanobacteria to average phytoplankton biomass in the Keszthely Basin of Lake Balaton between 1982 and 2000. (f) Annual average contribution of phytoflagellates to total biomass in the Keszthely Basin of Lake Balaton between 1982 and 2000. Trendline (second-order orthogonal polynomial) is also indicated in the graph. 
changes during the last 7 years indicates water quality improvement.

\section{Potentially mixotrophic species}

As was mentioned earlier, discharge from the River Zala, the most polluted (P-load) inflow, has been 'filtered' through a wetland area since 1992, which results in an increase in humic material load in the basin. Measurements of water colour (as Pt units) only started in 1997 (V.-BALOGH et al. 2000), and therefore longterm comparisons are not possible. However, the brownish, 'humic-material' colour of the Keszthely Basin was not observed prior to the present management steps. Recent investigations indicate a gradient in the colour of the lake water along its longitudinal axis, with the highest coloration in the Keszthely Basin. Phytoplankton species have different abilities in the utilization of organic (dissolved or particulate) matter. Experience shows that many flagellates occasionally use organic material as a source of carbon, and it is also known that highly humic waters support a high diversity of flagellates. However, this ability is not exclusive to flagellates, and similarly, there are flagellates that are strictly autotrophic. In this pilot approach, all flagellates were considered to be actually or potentially mixotrophic, and their share in total phytoplankton was investigated in the period between 1982 and 2000.

Prior to 1992 , the annual average contribution of flagellates remained largely below $10 \%$ (Fig. 2f). After this, it started to increase, and trendlines support the hypothesis that the share of flagellates would increase if the humic material load of a lake or lake basin increased. On the other hand, a lower standing crop of phytoplankton results in better light conditions, as indicated by the slow proliferation of submerged macrophytes (Sipos et al. 2000). Therefore, an increase of flagellates may integrate changes both in organic matter concentrations and in underwater light intensity/quality.

\section{Noise upon the process I: cornmunity structure analysis}

As was concluded in previous studies (e.g. ReYNOLDS et al. 1993), the seasonal succession of phytoplankton in any lake and in any particular year is governed both by internal mechanisms of community development and external factors which, considering the short generation times of the species involved, are in many cases derived from stochastic weather conditions. External impacts may reverse (the development of assembly is forced back to an earlier successional state but later it proceeds according to the expected pathway) or shift (after the external impact the community assembly follows a completely different pattern than expected) the pathway that is determined by internal processes. Analysis of any seasonal successional sequence is difficult unless several sequences (years) are taken into consideration, e.g. 19 sequences (years) in the present study. As described by PADISÁK \& ReYNOLDS (1998), the late summer composition of phytoplankton represents a kind of 'summarised outcome' of all previous events. Therefore, for community structure analysis the late summer compositions for the 19 years being studied were selected.

Community structure in terms of dominant species is given in Table 1 (see also 'Sources of data, methods and modelling' section herein). Records from this table were subjected to cluster analysis (Fig. 3). As percentage contributions were used as input data, the results are independent of absolute biomass records.

According to the results of the cluster analysis, and the recent classification system of phytoplankton assemblages (REYNOLDS 1997, see also PADISÁK \& ReYnolds 1998), the years 1982, 1984, 1985, 1986, 1988, 1989, 1992 and 1994 can be included in group $S_{H}$, characterised by an overwhelming dominance of Cylindrospermopsis raciborskii. A differential feature from association $S$ (see later) is the ability for fixing atmospheric N. Another group can be separated (years: 1990, 1991, 1995 and 1996) with $S-S_{H}$ species - a prominent feature of the species involved is the ability to live on minimal light energy; the ecophysiological background of this behaviour is the extremely low (10-30 $\left.\mu \mathrm{E} \mathrm{m}^{-2} \mathrm{~s}^{-1}\right) \mathrm{I}_{\mathrm{k}}$ parameter. Flagship species are Planktothrix agardhii, Limnothrix redekei and Pseudanabaena limnetica. During 1993, 1997 and 2000 , the late summer phytoplankton was 
Table 1. Late summer phytoplankton biomass $\left(\mathrm{mg} \mathrm{L}^{-1}\right)$ in the Keszthely Basin and contribution of the most abundant $(>3 \%)$ species to late summer total biomass.

\begin{tabular}{|c|c|c|c|c|c|c|c|c|c|c|c|c|c|c|c|c|c|c|c|}
\hline & 1982 & 1983 & 1984 & 1985 & 1986 & 1987 & 1988 & 1989 & 1990 & 1991 & 1992 & 1993 & 1994 & 1995 & 1996 & 1997 & 1998 & 1999 & 2000 \\
\hline Biomass $\left(\mathrm{mg} \mathrm{L}^{-1}\right)$ & 37.40 & 20.33 & 56.30 & 41.54 & 55.51 & 10.76 & 34.66 & 34.31 & 63.69 & 36.54 & 59.11 & 12.74 & 49.11 & 15.93 & 18.87 & 9.00 & 7.67 & 3.17 & 11.43 \\
\hline Cyanobacteria \% & 90 & 56 & 96 & 95 & 93 & 85 & 89 & 97 & 79 & 84 & 97 & 76 & 90 & 81 & 80 & 83 & 72 & 37 & 88 \\
\hline Snowella lacustris & & & & & & 4.9 & & & & & & 3.1 & & & & & 5.07 & & \\
\hline Anabaena circinalis & & & & & & & & & & & & & & & & & & 10.07 & \\
\hline Anabaena spiroides & & 29.7 & & 4.2 & & 24 & & & & & & 5.2 & & & & & & & \\
\hline Aphanizomenon aphanizomenoides & & 20.4 & 6.1 & 21 & & 28 & & 3.85 & & & & & & & & & & & 3.73 \\
\hline Aphanizomenon flos-aquae & & & & & & & & & & 4.6 & & & & 7 & & 31.7 & 27.96 & & 17.26 \\
\hline Aphanizomenon gracile & & & & & & & & & & & & & & & & 6.2 & & & \\
\hline Aphanizomenon klebahnii & & 3.5 & 5.6 & 7.9 & & 14 & 5.5 & $\cdot$ & 5 & 4.3 & & 24.2 & & 3.4 & 9.6 & 11.3 & & & \\
\hline Aphanizomenon issatschenkoi & & & & 13.4 & 7.6 & 5.8 & & & & 3 & & 17.6 & & 8.8 & 6.8 & 3.7 & & & 4.63 \\
\hline Cylindrospermopsis raciborskii & 82.26 & & 80.3 & 47.2 & 83.7 & 6.8 & 82.3 & 65.7 & 40.7 & 31.4 & 73.1 & 13.3 & 72.3 & 32.3 & 36.9 & 22.6 & 5.42 & & 44.81 \\
\hline $\begin{array}{l}\text { Lymnothrix planktonica }+ \\
\qquad \text { Pseudanabaena limnetica }\end{array}$ & & & & & & & & & & 5.7 & & & & & & & & & \\
\hline Lymnothrix redekei & & & & & & & & & & & 11.6 & & & & & & & & \\
\hline Planktolyngbya limnetica & & & & & & & & & 3 & & & & & & 3.4 & & & & \\
\hline Planktothrix agardhii & & & & & & & & 22.4 & 24.2 & 32 & 5.6 & 3 & 11.7 & 23.34 & 16.5 & 4.3 & & & \\
\hline Cryptomonas spp. & & 3.7 & & & & 3.2 & & & & & & & & 3.5 & & & & 9.83 & \\
\hline Ceratium birundinella & & 20.4 & & & & & & & & & & 5.2 & & & 3 & & 11.69 & 35.85 & \\
\hline Gymnodinium sp. & & & & & & & & & 3 & & & & & & & & & & \\
\hline $\begin{array}{l}\text { Aulacoseira granulata }+ \\
\qquad \text { A. granulata var. angustissima }\end{array}$ & & 11.9 & & & & & & & & & & & & & & & & & \\
\hline Navicula spp. & & & & & & & & & & & & & & 7.3 & & & & & \\
\hline Phacotus lenticularis & & & & & & & & & & & & & & & & & & 5.34 & \\
\hline Actinastrum hantzschii & & & & & & 4 & & & & & & & & & & & & & \\
\hline Scenedesmus opoliensis & & & & & & & & & 4 & & & & & & & & & & \\
\hline Mougeotia sp. & & & & & & & & & & 5.8 & & & & & & & & & \\
\hline Other species & 17.74 & 10.40 & 8.00 & 6.30 & 8.70 & 9.30 & 12.20 & 8.05 & 20.10 & 13.20 & 9.70 & 28.40 & 16.00 & 14.36 & 23.80 & 20.20 & 9.30 & 49.86 & 34.99 \\
\hline
\end{tabular}




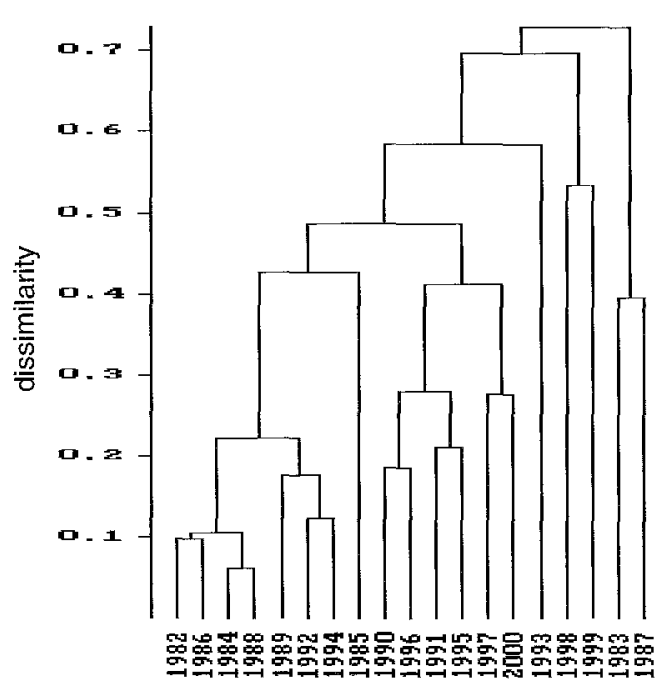

Fig. 3. Cluster dendrogram of data given in Table 1.

characterised by species of $\mathrm{H}$ (Aphanizomenon spp., Anabaena spp.) and $\mathrm{S}_{\mathrm{H}}$ groups. 1983, 1987,1998 and 1999 are loosely connected to each other and to other groups. In these years, late summer associations correspond to a mixture of $\mathrm{H}$ and $\mathrm{L}$ types, which represent associations closest to the pre-eutrophication period.

\section{Noise upon the process II: modelling the annual biomass of Cylindrospermopsis raciborskii}

As can be seen from the previous section, $C$. raciborskii has been playing a central role in the phytoplankton of Lake Balaton, both in quantitative and qualitative terms. The species is of tropical origin; therefore, its biomass determines total planktonic biomass exclusively in the season characterised by highest temperatures.

A careful analysis of meteorological data clearly shows that, in addition to water temperature, the underwater light climate can also be a limiting factor in eutrophication. For example, during 1996-1997 (comparing with, e.g., 1993) the wind conditions were unfavourable, resulting in the higher resuspension of inorganic particles and consequently more severe light limitation. The water quality is affected by resuspension and settling in at least two ways firstly, sediments suspended in the water column decrease light penetration, and secondly, the sediments are capable of acting as an internal source of nutrients.

Resuspension, light and temperature are random and uncontrollable factors influencing water quality trends, and they make it impossible to evaluate management strategies, due to the resulting chaotic nature of the data series.

The presented dynamic model was used to resolve this problem by separating controllable (e.g. external nutrient load) and uncontrollable elements of the eutrophication processes.

The steps of the analysis are: (i) the calibration and (ii) validation of the model based on the biomass data of $C$. raciborskiz; then (iii) a sensitivity analysis is conducted to clarify the relative weights of the different factors influencing algal bloom.

Calibration and validation were performed for Keszthely Basin. The external nutrient load of this basin can be estimated precisely, because it broadly coincides with the load carried by the Zala River (main tributary of Lake Balaton).

The input variables are water inflow, external $P$ loading, water temperature, and solar radiation. In most cases, daily data were available for the period 1982-1999 (otherwise interpolation was applied). Different $\mathrm{P}$ fractions from the external load enter the $\mathrm{P}$ compartments of the models according to detailed studies on $\mathrm{P}$ fractions (ISTVÁNOVICS \& SOMLYÓdY 1997).

For the purpose of calibration, C. raciborskii biomass data were applied. Certain years were chosen for calibration, and independent years for validation. An adaptive random search method (Koncsos 1994) was applied for the calibration purpose.

Calibration results for the $C$. raciborskii biomass from 1988 are in close agreement with measured and computed biomass values (Fig. 4a). The parameters obtained were in close agreement with the literature.

Validation was carried out for the years 1986-1998 (Fig. 4b) using the fixed parametervector determined for 1988 .

For sensitivity analysis, a reference year that could be characterised by high measured $C$. 

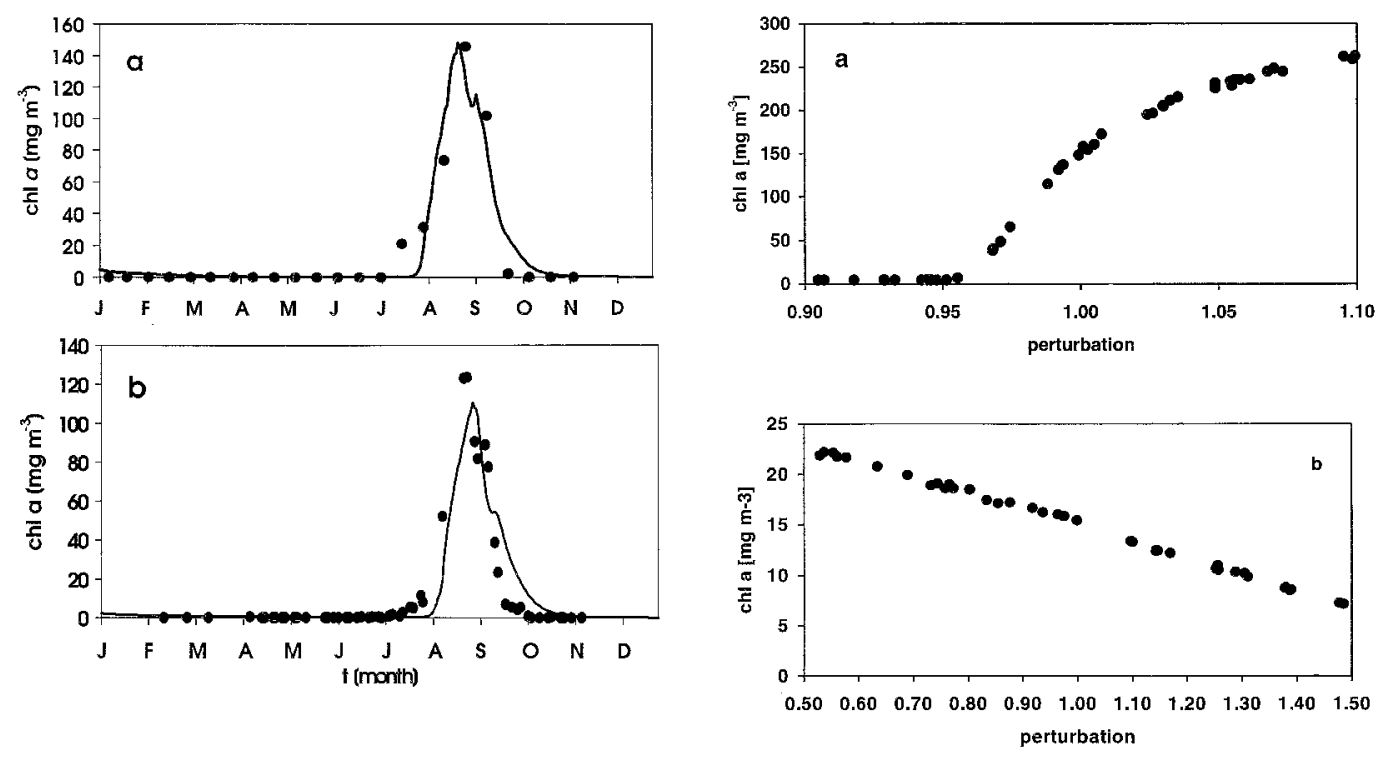

Fig. 4. (a) Calibration of the model for the chlorophyll concentration of $C$. raciborskii (data from 1988). (b) Validation of the model for the chlorophyll concentration of $C$. raciborskii (data from 1992).

raciboskii biomass and high internal $\mathrm{P}$ load was chosen. Since 1988 satisfies these criteria, the random perturbation of the input variables on a Monte Carlo model mirrors biomass sensitivity to the given factors separately. This type of uncertainty analysis can be considered as an investigation under unfavourable water quality conditions; therefore, the results are the upper limits of estimation of the influences of the investigated forcing functions.

The input flow rate of the Zala River, temperature, throughflow, wind speed, external load were perturbed separately in different sensitivity runs.

Three observations resulting from the sensitivity analysis of $C$. raciborskii are:

1. C. raciborskii is extremely sensitive to small changes of temperature. Only 10\% of the perturbation of water temperature time series determines if an algal bloom can be observed (Fig. 5a). This result is in agreement with other studies (G.-Tóтн \& Padisák 1986, PADIsák \& IstVánovics 1997, PADISÁK 1998).

Fig. 5. (a) Response of annual maximum C. raciborskii biomass (expressed as chlorophyll $a$ ) due to the perturbation ( $\mathrm{p}$, a random multiplier with no dimension) of the water temperature (year 1988). P $=1$, no perturbation. (b) Response of annual mean C. raciborskii biomass (expressed as chlorophyll $a$ ) due to the perturbation ( $\mathrm{p}$, a random multiplier with no dimension) of the wind speed (year 1988). $\mathrm{P}=1$, no perturbation.

2. The biomass is not sensitive to the throughflow (and residence time of the basin) $50 \%$ perturbation in the residence time causes only $5 \%$ change in the maximum biomass concentration. This model result has been in agreement with wide habitat diversity (therefore wide range of retention times) of lakes where C. raciborskii occurs. Moreover, it accords with the observation that $C$. raciborskii is the cyanobacterium for which the longest riverine travel distance can be documented (PADISÁK 1997).

3. The yearly average biomass is very sensitive to wind speed and resuspension (Fig. 5b). This is a complex response in agreement with the first observation. However, the effects of wind-induced changes in light conditions due to resuspension are contradictory to the second observation. Relation- 
ships will have to be further analyzed, incorporating interactions (competition) between different guilds of phytoplankton instead of using just a single algal compartment as in the present study. Most probably, chlorococcalean $r$-strategists are the main competitors (PADISÁK \& G.-TÓTH 1991).

\section{Conclusions}

In this work, a complex approach was adopted to attempt to explain the trendlike changes and stochasticity of phytoplankton under the eutrophication and restoration forces of the largest shallow lake of Central Europe. This complex approach involved both studies of community ecology and analytic and predictive studies of dynamic ecological modelling.

In both models, external load was found to be responsible for trend-like changes, including not only phytoplankton biomass responses to increasing/reduced external P loadings, but also the compositional response of phytoplankton to qualitative changes (dissolved organic carbon fraction) of nutrient loading (increase in share of flagellates). These trends, however, are occasionally sheltered by the actual status of weather(climate)-dependent internal loadings, and the growth limitations which impose significant noise upon the process and decrease the predictability of the outcome of lake restoration management. Recent model runs conclude that the relatively rapid response of phytoplankton to restoration is more a result of 'noise upon process' (consecutive years with low internal $P$ load) than that of restoration.

At present, and taking both trends (external load, internal $\mathrm{P}$ pool) and noise (frequency of regular mesoclimatic cycles) into consideration, high phytoplankton biomass (especially Cyindrospermopsis raciborskii) may occur at any time in the next 10 years.

\section{Acknowledgemet}

This work was supported by the "Phytoplanktonon-line" EC-RTD (5th Framework) Project.

\section{References}

Czekanowski, J., 1909: Zur differential Diagnose der Neandertalgruppe. - Korrespbl. dt. Ges. Anthrop. 40: 4447.

G.-TotH, L. \& PADISAK, J., 1986: Meteorological factors affecting the bloom of Anabaenopsis raciborskii Wolosz. (Cyanophyta: Hormogonales) in the shallow Lake Balaton, Hungary, - J. Plankton Res, 8: 353-363.

HERodeK, S., 1984: The eutrophication of Lake Balaton: Measurements, modeling and management. - Verb. Internat.
Verein. Limnol. 22: 1087-1091.

Herodek, S. \& TAMAS, G., 1975: The primary production of phytoplankton in the Keszthely Basin of Lake Balaton in 1973-1974. - Annal. Biol. Tihany 42: 175-190.

IsTVANOVICS, V. \& SOMLYODY, L., 1997: Functioning of the Upper Kis-Balaton Reservoir - Budapest University of Technology. Manuscript, Budapest, pp.62. (in Hungarian).

Istvánovics, V., Kovács, A., Vörös, L., Herodek, S. \& PomOGYT, P., 1997: Phosphorus cycling in a large, reconstructed wetland, the lower Kis-Balaton reservoir (Hungary). - Verh. Internat. Verein Limnol. 26: 332-339.

Koncsos, L., 1994: The Model System and Software Package REWARD (Regional Water Quality and Resources Decision Model). - Bochum, Germany. p.163.

Kutas, T. \& Herodek, S., 1982: A Short Description of Balaton Eutrophication Model (BEM). - SZTAKI Working Paper MS-9.

OlAh, J., El Samra, K. I., Abdel Moneim, M. A., Tóth, L. \& VöRös, L., 1981: Nitrogénkötés halhústermelö agroekoszisztámákban [Nitrogen fixation in ecosystems used for fish farming]. Kellás, Budapest, pp. 208 (In Hungarian with English summary)

PADISAK, J., 1993: The influence of different timescale disturbances on the species richness, diversity and equitablity of phytoplankton in shallow lakes. - Hydrobiologia 249: 135-156.

PADISAK, J., 1997: Gylindrospermopsis raciborskii (Woloszynska) Seenayya et Subba Raju, an expanding, highly adaptive cyanobacterium: worldwide distribution and review of its ecology. - Arch. Hydrobiol./Suppl. 107(Monographic Studies): 563-593.

PADISÁ, J., 1998: Sudden and gradual responses of phytoplankton to global climate change: case studies from two large, shallow lakes (Balaton, Hungary and the Neusiedlersee Austria/Hungary). - In: GeORGE, D. G., Jones, J. G., Puncochar, P., Reynolds, C. S. \& Sutcliffe, D. W. (eds): Management of Lakes and Reservoirs During Global Change: 111-125. - Kluwer Acad. Publ., Dordrecht, Boston. London.

PADISAK, J. \& ADRIAN, R., 1999: Chapter 5. 1, Biovolumen. In: Tumpling, W. \& Friedrich, G. (eds) Methoden der Biologischen Wasseruntersuchung 2. Biologische Gewässeruntersuchung: 334-367. - Gustav Fischer Verlag, Jena.

PADISAK, J. \& G.-Tóth, L., 1991: Some aspects of the ecology of the subdominant green algae in a large nutrient limited shallow lake (Balaton, Hungary). - Arch. Protistenkunde 139: 225-242.

Padisák., J. \& IstÝñnovics, V., 1997: Differential response of blue-green algal groups to phosphorus load reduction in a large shallow lake: Balaton, Hungary. - Verh. Internat. Verein. Limnol. 26: 574-580.

PADISAK, J. \& ReYNOLDS, C. S., 1998: Selection of phytoplankton associations in Lake Balaton, Hungary, in response to eutrophication and restoration measures, with special reference to cyanoprokaryotes. - Hydrobiologia 384: 41-53

PadisAK, J., Krienitz, L. \& SchefFler, W., 1999: Chapter 


\section{J. Padisák \& L. Koncsos, Long-term changes in phytoplankton in the Keszthely Basin}

3.6.1., Phytoplankton. - In: Túmpling, W. \& Friedrich, G. (eds): Methoden der Biologischen Wasseruntersuchung 2. Biologische Gewässeruntersuchung. 35-52. - Gustav Fischer Verlag, Jena.

PoDAnI, J., 1988: Syn-Tax III. User's manual. - Abstr. Botanica 12: $1-183$.

ReYNolds, C. S., 1997: Vegetation Processes in the Pelagic: a Model for Ecosystem Theory. - Ecology Institute, Oldendorf/Luhe.

ReYNolds, C. S., PADISÁK, J. \& SOMMER, U., 1993: Intermediate disturbance in the ecology of phytoplankton and the maintenance of species diversity: a synthesis. - Hydrobiologia 249: 183-188.

SAS, H., 1989: Lake Restoration and Reduction of Nutrient Loading: Expectations, Experiences, Extrapolations. - Academia Verlag, Richarz, St. Augustin.

SIPOS, K., PADISÁK, J. \& HAHN, I., 2000: Hínárvegetáció vizsgálatok a Keszthelyi-öbölben [Studies on submerged macrophytes in the Keszthely Bay of Lake Balaton]. - Hidrologiai Közlöny 80: 345-347 (in Hungarian with English summary).

SOMLYód, L. \& JoláNKaI, G., 1986: Nutrient loads. - In: Somlyódy, L. \& van Straten, G. (eds): Modeling and Managing Shallow Lake Eutrophication. - Springer Verlag, Berlin, 125-156.

Somlyóny, L. \& van Straten, G., 1986: Modeling and Managing Shallow Lake Eutrophication. - Springer-Verlag, Berlin, Heidelberg, New York, Tokyo.

SOMmer, U., PAdisák, J., Reynolds, C. S. \& Juhász-Nagy, P., 1993: Hutchinson's heritage: the diversity-disturbance relationship in phytoplankton. - Hydrobiologia 249: 1-8.

TAMÁs, G., 1965: Horizontale Plankton-Untersuchungen im Balaton VI. über das Phytoplankton im südwestlichen Teil des Sees auf Grund von Schöpf- und Netzfilterproben vom July 1962. - Annal. Biol. Tibany 32: 229-245.

TAMAs, G., 1967: Horizontale Plankton-Untersuchungen im Balaton V. Über das Phytoplankton des Sees auf Grund der im Jahre 1965 grschöpften und Netzfilterproben. - Annal. Biol. Tihany 34: 191-231.
TAMÁs, G., 1969: Horizontal plankton investigations in Lake Balaton VII. On the phytoplankton of Lake Balaton, based on scooped samples and filtrates taken in 1966. - Annal Biol. Tihany 36: 257-292.

TAMAs, G., 1972: Horizontal phytoplankton studies in Lake Balaton based on scooped samples and filtrates taken in 1967. - Annal. Biol. Tihany 39: 151-188.

TAMAs, G., 1974: Die Algenflora des Balaton-Sees (Zusammengestellt nach Angaben aus den Jahren 1959-1963). Annal. Biol. Tihany 31: 245-253.

TAMÁs, G., 1975: Horizontally occurring quantitative phytoplankton investigations in Lake Balaton, 1974. - Annal. Biol. Tihany 42: 219-280.

V.-Balogh, K., Vörös, L. \& Kovacs, A., 2000: Oldott huminanyagok hatása a Balaton vízminōségére. [Effect of dissolved humic materials on the water quality of Lake Balaton]. - In: Somlyódy, L. \& Banczerowski, J. (eds): Results of Balaton Research in 1999: 151-160. - ISSN 14191075, MTA, Budapest (in Hungarian).

VOlLenweider, R. A. \& Kerekes, J. J., 1982: Background and summary results of the $O E C D$ cooperative programme on eutrophication. - OECD Report, Paris.

Vörös, L., 1980: A Balaton fitoplanktonjának tömege, összetétele és diverzitása 1976-ban [Masse, Zusammensetzung und Diverzität der Phytoplankton im Balaton in Jahre 1976]. - Bot. Koezl. 67: 25-33 (in Hungarian with German summary).

Authors' addresses:

J. PADISÁK, Institute of Biology, University of Veszprém, H-8200 Veszprém, Egyetem u. 10, P. O. Box 158, Hungary.

E-mail: padisak@tres.blki.hu.

L. Koncsos, Budapest University of Technology and Economics, Department of Sanitary and Environmental Engineering, H-1111 Budapest, Mûegyetem rkp. 3, Hungary. 